JPdK Volume 2 No 2 Tahun 2020 Halaman 174-178 JURNAL PENDIDIKAN dan KONSELING

\title{
Peningkatan Keterampilan Proses IPA Dengan Menggunakan Model Inquiri Terbimbing Di Sekolah Dasar
}

\author{
Hotmayati Sitorus ${ }^{1}$ Yenni Fitra Surya ${ }^{2}$ \\ Pendidikan Guru Sekolah Dasar \\ Fakultas Ilmu Pendidikan \\ Universitas Pahlawan Tuanku Tambusai \\ Email :sitorushotmayati@gmail.com
}

\begin{abstract}
Abstrak
Penelitian tindakan kelas ini dilatarbelakangi oleh rendahnya keterampilan proses pada mata pelajaran IPA siswa kelas V Madrasah Ibtidaiyah AL-Ikhlas, Batam. Penelitian ini bertujuan untuk meningkatkan keterampilan proses melalui inquiri terbimbing pada mata pelajaran IPA.Jenis penelitian ini adalah Penelitian Tindakan Kelas (PTK). Model penelitian yang digunakan yaitu model Spiral kemmis dan Taggart. Subjek penelitian ini adalah siswa kelas V Madrasah Ibtidaiyah AL-Ikhlas, Batam. Data yang dikumpulkan adalah data proses pembelajaran menggunakan inquiri terbimbing pada mata pelajaran IPA. Teknik pengumpulan data yang digunakan yaitu observasi.Instrumen yang digunakan adalah lembar observasi. Data yang diperoleh dari hasil observasi dianalisi secara deskkriptif kuantitatif dan deskriptif kualitatif. Deskriptif kuantitatif adalah cara membandingkan skor pengamatan dari hasil setiap siklus. Sedangkan deskriptif kualitatif adalah dengan menjelaskan proses pembelajaran menggunakan inquiri terbimbing yang dilakukan pada setiap siklus.Hasil penelitian menunjukkan bahwa penggunaan inquiri terbimbing dapat meningkatkan keterampilan proses IPA siswa kelas $\mathrm{V}$ pada mata pelajaran IPA di Madrasah Ibtidaiyah AL-Ikhlas, Batam. Adapun langkah-langkah yang dilakukan berdasarkan model inquiri terbimbing dalam proses pembelajaran yaitu mengajukan pertanyaan yang berkaitan dengan materi, merumuskan masalah yang ditemukan, merumuskan hipotesis, melakukan eksperimen sederhana,menganalisis data, dan menarik kesimpulan. Peningkatan ditunjukkan dengan pencapaian keterampilan proses siswa pada mata pelajaran IPA saat pratindakan termasuk kategori kurang yaitu hanya mencapai 43,12 dan hanya ada 3 siswa (15\%) yaang mendapat nilai diatas KKM. Setelah diberikan tindakan pada siklus I yaitu dengan menerapkan metode inquiri terbimbing dalam pembelajaran IPA, keterampila siswa meningkat dengan rata-rata $65 \%$ dan ada 13 siswa $(65 \%)$ yang mendapat nilai KKM. Pada siklus II pencapaian keterampilan proses meningkat mencapai rata-rata $86,25 \%$ dan siswa yang mendapat nilai diatas KKM terdiri dari 17 siswa (90\%) setelah dilakukan perbaikan pada tahap merumuskan hopotesis, melakukan eksperimen sederhana, dan menganalisis data dalam melaksanakan inquiri terbimbing.
\end{abstract}

Kata Kunci :Keterampilan Proses, Inquiri Terbimbing, Mata Pelajaran

\begin{abstract}
The background of this class action study is cause of minimum process skill science course to 5th grade student madrasah ibtidaiyah al-ikhlas,batam. This research is purpose to improve process skill through guided inquiry on science course. The kind of this research is class action research (ptk). The model of this research using spiral kemmis and taggart. Research subject is 5th grade student madrasah ibtidaiyah alikhlas batam. The collected data is learning process data using guided inquiry in science subjects. The technique of collecting data is using observation. Data obtained from observation analyzed by compare the observed scores of the results of each cycle(descriptive qualitative) and explain the learning process
\end{abstract}


using guided inquiry which is carried out in each cycle(qualitative descriptive. The result of this research shows that guided inquiry can improve process science skill on student. The step for guided inquiry on learning process is asking question related on theory, define the problem, analyzing data, and take a conclusion. The improvement showed by milestones of learning process subject on science course while pre-action in less category $(43,12)$ and only 3 student $(15 \%)$ who got pass the minimum standard. After giving guided inquiry method on science course, average student skill improve to 65,45 and 13 student (65\%) got minimum standard pass. On second cycles, milestones of learning process improve to average 85 and 17 student $(85 \%)$ who got the minimum standard after fixing on define hypothesis, do simple experiment, and analyze data in doing guided inquiry

\section{Keywords : Process Skill, Guided Inquiry, Science Course}

\section{PENDAHULUAN}

Pendidikan adalah sebuah proses dengan metode-metode tertentu sehingga orang memperoleh pengetahuan, pemahaman dan cara bertingkah laku yang sesuai dengan kebutuhan. Tujuan pendidikan pada dasarnya adalah membentuk sumber daya manusia yang berkualitas, seperti yang disebutkan di dalam UUD 1945 (versi amandemen), pasal 31 ayat 3 bahwa pemerintah mengusahakan dan menyelenggarakan satu sistem pendidikan nasional, yang meningkatkan keimanan dan ketakwaan serta akhlak mulia dalam rangka mencerdaskan kehidupan bangsa.

Untuk dapat mencapai tujuan pendidikan tersebut maka diperlukan adanya peningkatan mutu pendidikan, dan hal yang mungkin dilakukan di dalam meningkatkan mutu pendidikan adalah dengan meningkatkan kualitas guru, memperbaiki kurikulum, sistem pendidikan bahkan proses kegiatan belajar mengajar di sekolah. Proses pembelajaran merupakan suatu proses interaksi antara peserta didik dengan guru sebagai pengajar yang meliputi unsur-unsur manusiawi, material, fasilitas, perlengkapan dan prosedur yang saling mempengaruhi dalam mencapai tujuan pembelajaran. Dalam proses pembelajaran guru sangat berperan penting dalam keberhasilan pencapaian tujuan pelajaran. Guru tidak hanya dituntut untuk menguasai bidang studi yang akan diajarkan saja, tetapi juga harus menguasai dan mampu mengajarkan pengetahuan dan keterampilan pada peserta didikkarenakeberhasilan sebuah kurikulum sangat ditentukan oleh mutu pembelajaran yang dilakukan oleh guru dimana sebuah kurikulum dikatakan berhasil jika tujuan pendidikan tersebut dapat tercapai. Pada Sekolah Dasar terdapat beberapa mata pelajaran yaitu matematika, bahasa Indonesia, IPS, PKN, IPA dan sebagainya, semua pembelajaran tersebut memiliki arti penting masing-masing di Sekolah Dasar (SD) salah satu mata pelajaran yang wajib dipelajari oleh siswa SD yaitu mata pelajaran IPA.

Ilmu Pengetahuan Alam (IPA) merupakan ilmu yang mempelajari tentang gejala alam yang dituangkan berupa fakta, konsep, prinsip, dan hukum yang teruji kebenarannya dan melalui suatu rangkaian kegiatan dalam metode ilmiah. Ilmu Pengetahuan Alam (IPA) adalah salah satu mata pelajaran yang diajarkan pada tingkat Sekolah Dasar (SD). Mata pelajaran IPA merupakan mata pelajaran yang menanamkan dan mengembangkan pengetahuan dan kemampuan, sikap dan nilai ilmiah pada siswa. Menurut Patta Bundu (2006:9-11), Secara garis besar IPA memiliki tiga komponen, yaitu: (1) proses ilmiah seperti mengamati, mengklasifikasi, memprediksi, merancang, dan melaksanakan eksperimen, (2) produk ilmiah seperti prinsip, konsep, hukum, dan teori, serta (3) sikap ilmiah seperti sikap ingin tahu, objektif dan jujur.

Pengembangan sikap ilmiah sebagai salah satu dimensi IPA Sulistyorini (dalam juhji 2007:9), menyatakan bahwa pada hakikatnya IPA adalah suatu mata pelajaran dengan menekankan pada proses belajar mengajar yang aktif karena IPA memiliki tiga dimensi penting yang menyusunnya yaitu dimensi produk yang berisi hasil dari proses penemuan ilmu pengetahuan yang biasanya berupa teori maupun hukum, dimensi proses yang biasa menekankan bagaimana proses yang dilalui untuk mendapatkan suatu pengetahuan dan dimensi 
pengembangan sikap ilmiah yang berisi pengembangan-pengembangan sikap ilmiah di dalam proses untuk menghasilkan dan menemukan sebuah pengetahuan atau produk IPA. Pada dasarnya pelaksanaan pembelajaran IPA diharapkan dapat mengembangkan aspekaspek tersebut, agar pembelajaran IPA bermakna bagi siswa di Sekolah Dasar (SD).

Proses-proses IPA yang dilakukan siswa tersebut terdiri dari berbagai keterampilan yang dikenal dengan keterampilan proses IPA Keterampilan proses adalah keterampilan ynag diperoleh dari latihan kemampuan mental, fisik, dan sosial yang mendasar sebagai penggerak kemampuan-kemampuan yang lebih tinggi Wahyana (dalam Trianto 2015:144). Keterampilan proses sangat penting dimiliki seorang siswa, karena keterampilan proses merupakan cara yang khas dalam menghadapi pengalaman yang berkenaan dengan semua segi kehidupan yang relevan bagi siswa, Adapun indikator keterampilan proses yaitu observasi, klasifikasi, aplikasi konsep, prediksi, interprestasi, menggunakan alat, eksperimen, mengkomunikasikan dan mengajukan pertanyaan selanjutnya didalam keterampilan proses siswa diharapkan ikut serta dan aktif dalam kegiatan mengobservasi, eksperimen, mengklasifikasi dan mengkomunikasikan Kemudian guru sangat berperan penting dalam kegiatan pembelajaran sehingga mampu menumbuhkan semangat siswa dalam belajar, sehingga keterampilan proses siswa dalam kegiatan pembelajaran dapat meningkat.

Berdasarkan Observasi peneliti pada Selasa, 12 November 2019 terlihat dalam proses belajar mengajar IPA siswa masih banyak yang tidakmemahami materi yang diajarkan kemudian peneliti mengambil data pratindakan didapatkan siswa yang tuntas hanya 3 orang siswa dengan persentase klasikal 15\% dan siswa tidak tuntas mencapai 17 orang siswa dengan persentase klasikal $85 \%$. Hal tersebut dikarenakan guru tidak pernah melatih siswa untuk mengembangkan keterampilan proses seperti pengumpulan data dengan melakukan eksperimen dan mengadakan pengamatan, siswa kurang antusias dan tertarik pada materi karena guru menggunakan metode konvensional dalam mengajar. Pembelajaran dengan metode konvensional tak lebih dari transfer ilmu guru kepada siswa didalam kelas melalui komunikasi satu arah. Siswa hanya menjadi obyek pasif yang mempunyai kewajiban untuk menghafal catatan yang telah diberikan guru supaya bisa menjawab soal-soal yang nantinya akan diujikan. Proses pembelajaran IPA masih didominasi oleh guru sehingga siswa kurang aktif dalam pembelajaran. Siswa hanya mendengarkan guru serta mencatat apa yang di informasikan guru tanpa ada pengalaman secara langsung, sehingga kurang memberikan pengalaman langsung bagi siswa, hal tersebut mengakibatkan keterampilan proses dan sikap ilmiah siswa kurang berkembang. Pembelajaran IPA semestinya. Permasalahan guru yang kesulitan untuk menyampaikan materi yang akan diajarkan membuat siswa tidak memahami materi yang diajarkan guru. Kondisi kelas yang tidak kondusif, siswa asyik bermain dan tidak mendengarkan penjelasan dari guru membuat suasana kelas menjadi ribut dan tidak tenang. Sikap siswa yang tidak mengerti dengan materi yang diajarkan guru, maka guru perlu strategi pembelajaran yang baru (dalam Pebriana 2017) Memperhatikan masalah yang terjadi, maka perlu diadakan penelitian untuk meningkatkan keterampilan proses pembelajaran IPA di Sekolah Dasar,Salah satunya adalah dengan menggunakan Model Inkuiri Terbimbing dalam pembelajaran IPA yang dapat meningkatkan aktivitas belajar IPA pada siswa Sekolah Dasar.Modelinquiri terbimbing yaitu model inkuiri dimana guru membimbing siswa melakukan kegiatan dengan memberi pertanyaan awal dan mengarahkan pada suatu diskusi.Menurut Suyanti (2010) model inquirimerupakan pembelajaran yang berpusat pada siswa yang memiliki peran untuk mencari dan menemukan sendiri materi pelajaran, sedangkan guru berperan sebagai fasilitator untuk mendorong siswa dapat mengembangkan disiplin intelektual dan keterampilan berfikir dengan memberikan pertanyaanpertanyaan.Model pembelajaran harus nya digunakan dalam setiap pembelajaran agar pembelajaran efektif inofatif dan menyenangkan.Salah satu yang dapat digunakan yaitu model pembelajaran inkuiri. Inkuiri merupakan suatu jenis teknik simulasi yang umumnya digunakan untuk pendidikan sosial dan hubungan antar insan (Surya, Y.F 2017) 
Model inquiri terbimbing menekankan pada proses penemuan sebuah konsep sehingga muncul sikap ilmiah pada diri siswa. Siswa SD memiliki sifat yang aktif, sifat ingin tahu yang sangat besar, terlibat dalam suatu situasi secara utuh terhadap suatu proses dan hasil-hasilnya yang ditemukan. Model inquiri terbimbing dapat dirancang penggunaannya oleh guru menurut tingkat perkembangannya.Inkuiri terbimbing menuntut guru membimbing siswa dengan

\section{METODE PENELITIAN}

Penelitian ini dilakukan di Kelas V Madrasah Ibtidaiyah AL-Ikhlas yang beralamat di JL. Mangsang Indah blok C, Tanjung Piayu, Batam. Alasan penulis mengadakan penelitian di lembaga tersebut adalah: sebagai tempat penulis menjalankan aktivitas sebagai guru mata pelajaran sehingga penulis mengetahui kondisi sekolah tersebut. Berdasarkan pengamatan kondisi sekolah tersebut, maka penulis tertarik untuk memberikan kontribusi untuk meningkatkan mutu pembelajaran bagi siswa di Madrasah Ibtidaiyah AL-Ikhlas.

Subjek penelitian ini adalah guru bidang studi IPA kelas V dan seluruh siswa kelas V di Madrasah Ibtidaiyah ALIkhlas. Dengan jumlah siswa sebanyak 20 orang, perempuan 11 orang dan laki-laki 9 orang Pertimbangan dipilihnya kelas tersebut didasarkan pada temuan masalah bahwa kemampuan IPA siswa kelas tersebut masih rendah. Metode penelitian adalah cara yang digunakan oleh peneliti dalam mengumpulkan data penelitian. Metode yang digunakan dalam penelitian ini adalah penelitian tindakan kelas. Menurut Arikunto (2012:3) mengatakan bahwa PTK memiliki 3 usur atau konsep yaitu : Penelitian adalah kegiatan mencermati suatu objek dengan menggunakan cara atau aturan metedologi tertentu untuk memperoleh data untuk meningkatkan mutu suatu hal yang menarik minat bagi peneliti

\section{HASIL PENELITIAN DAN PEMBAHASA}

Peneliti melakukan observasi terhadap keterampilan proses siswa untuk mengetahui kondisi awal keterampilan proses dasar IPA siswa. Hasil observasi menunjukkan bahwa keterampilan proses dasar IPA siswa masih rendah. Rendahnya keterampilan proses dasar memberikan petunjuk berupa pertanyaanpertanyaan yang bersifat membimbing. Model Inquiri terbimbing juga dapat menjadikan pembelajaran menjadi lebih bermakna dan mudah dimengerti serta dipahami oleh siswa. Selain itu model pembelajaran inquiri terbimbing ini juga bisa menciptakan kondisi belajar dimana siswa aktif terlibat dan guru berperan sebagai fasilitator pembelajaran yang sangat membantu dalam mencapai tujuan belaj

1) Tindakan adalah suatu gerak kegiatan yang dilakukan dengan tujuan tertentu. Dalam penelitian berbentuk rangkaian siklus kegiatan untuk siswa.

2) Kelas adalah sekelompok peserta didik dalam waktu sama, menerima pelajaran yang sama dari guru yang sama pula.

Dengan menggabungkan batasan pengertian tiga kata ini, yaitu: penelitiantindakan-kelas, dapat disimpulkan bahwa penelitian tindakan kelas merupakan suatu pencermatan terhadap kegiatan belajar berupa sebuah tindakan, yang sengaja dimunculkan dan terjadi dalam sebuah kelas secara bersama. Tindakan tersebut diberikan oleh guru atau dengan arahan dari guru yang dilakukan oleh siswa.

Penelitian tindakan kelas atau PTK memiliki peranan yang sangat penting dan strategis untuk meningkatkan mutu pembelajaran apabila diimplementasikan dengan baik dan benar.Diimplementasikan dengan baik, artinya pihak yang terlibat dalam PTK (guru) mencoba dengan sadar mengembangkan kemampuan dalam mendeteksi dan memecahkan masalah-masalah yang terjadi dalam pembelajaran di kelas melalui tindakan bermakna yang diperhitungkan dapat memecahkan masalah atau memperbaiki situasi dan kemudian secara cermat mengamati pelaksanaannya untuk mengukur tingkat keberhasilannya.

siswa ditunjukkan dengan adanya siswa yang masih belum mampu mendeskripsikan hasil pengamatannya secara detail. Saat tanya jawab dengan guru, tidak ada seorang pun siswa yang dapat membuat prediksi. Selain itu, banyak siswa yang tidak dapat mengomunikasikan hasil perolehan pertanyaan yang diberikan guru, serta 
siswa cenderung diam dan pasif selama proses pembelajaran.Rendahnya keterampilan proses dasar IPA siswa dikarenakan pembelajaran yang berlangsung kurang menekankan pada pengembangan keterampilan tersebut. Pembelajaran yang berlangsung lebih menekankan pada penguasaan materi.Siswa hanya diberi tugas untuk mencatat materi yang dipelajari, baik dari penjelasan guru maupun dari buku.Selain itu, siswa hanya diberi tugas mengerjakan soal-soal mengenai materi yang dipelajari. Siswa kurang diberi kesempatan untuk mengembangkan keterampilannya melalui proses belajar penemuan

\section{SIMPULAN}

Berdasarkan hasil penelitian dan
pembahasan, maka dapat disimpulkan bahwa: Penerapan metode inquiri terbimbing dapat meningkatkan keterampilan proses siswa. Hal tersebut

\section{DAFTAR PUSTAKA}

Arikunto (2012).Penelitian Tindakan Kelas . Jakarta

Juhji (2016).Peningkatan Keterampilan Proses Sains Siswa melalui Pendekatan Inkuiri Terbimbing.Jurnal PGSD

Mujakir (2015). Kreativitas Guru Dalam Pembelajaran IPA di Sekolah Dasar, Lantanida jurnal vol.3, no.1,83-89

Kontekstual.Jurnal Pena Ilmiah Vol.2 no. $1,651-660$

Patta Bundu. (2006).Penilain Keterampilan Proses dan Sikap Ilmiah Dalam
IPA meningkat. Keterampilan proses siswa meningkat dengan rata-rata $65 \%$ (kategori cukup baik) dan terdapat 13 siswa yang mendapatkan nilai di atas KKM. Pada siklus II pencapaian keterampilan proses meningkat mencapai rata-rata $86,25 \%$ (kategori baik ) dan ada 18 siswa yang mendapatkan nilai di atas KKM setelah dilakukan perbaikan pada tahap merumuskan hipotesis, melakukan eksperimen sederhana, dan menganalisis data dalam melaksanakan inquiri terbimbing. Perolehan tersebut sudah memenuhi kriteria keberhasilan dalam penelitian ini.

ditunjukkan dengan pencapaian keterampilan proses siswa pada mata pelajaran IPA saat pra tindakan termasuk kategori kurang. Setelah diberikan tindakan pada siklus I yaitu dengan menerapkan metode inquiri terbimbing dalam pembelajaran

Pembelajaran Sains SD. Jakarta: Depdiknas Dirjen Dikti

Pebriana, P.H (2017).Peningkatan Keterampilan Menulis Puisi Bebas Menggunakan Pendekatan Kontekstual Siswa Sekolah Dasar. Jurnal PGSD

Surya, Y.F (2017). Peningkatan Hasil Belajar Siswa IPS Menggunakan Model Inkuiri Sekolah Dasar. Jurnal PGSD

Suyanti (2007).Model Pembelajaran IPA Sekolah Dasar.Yogyakarta :Tiara Wacana

Wahyana.(2010). Keterampilan Proses dalam Keterampilan IPA. Jakarta: PTK IPA 